\title{
The Application of EF Analysis in Quantitative Assessment of Sustainable Development
}

\author{
Yang Chen* and Yuxue Cao \\ Shenzhen University, Shenzhen, Guangdong, China \\ ${ }^{*}$ Corresponding author
}

\begin{abstract}
Quantitative measures for sustainable development are important topics and frontier areas of sustainable development research. The core of this paper is to determine whether human beings live within the bearing capacity of ecosystems. This paper introduces the ecological footprint method, which is proposed by Wackernagel $M$ and other sustainable development since 1996, and uses this method to calculate and analyze the ecological footprint of Guangdong Province in 2015. The results show that the per capita ecological footprint deficit of Guangdong Province in 2015 is $1.64832 \mathrm{hm}^{2}$. Reflecting the current production and living intensity of Hubei Province has exceeded the carrying capacity of ecosystems, and regional ecosystems are under the excessive exploitation and pressure of human beings.
\end{abstract}

Keywords-ecological footprint; ecological carrying capacity; ecological deficit; Guangdong Province

\section{INTRODUCTION}

Ecological footprint is a way to measure the degree of sustainable development from an ecological point of view. At present, nearly 20 countries have used the ecological footprint to calculate the bearing capacity of various types. The WWF and the redefined development organization have also released the ecological footprint information of the world every two years since 2000. In China, the concept of ecological footprint was introduced in 1999, after which many scholars have systematically introduced and studied it. Based on the ecological footprint method and the human development index, this paper analyzes and evaluates the social sustainable development of Guangdong Province in 2015

\section{PRINCIPLE AND METHOD}

\section{A. The Concept of Ecological Footprint}

The ecological footprint of a known population (individual, city or country) is the production of all the resources consumed by the corresponding population and the amount of bioproductive land needed to absorb all the wastes produced by these populations. The calculation is based on two basic facts: (1) human beings can estimate the majority of their own consumption of resources, energy and the amount of waste generated by it; (2) these resources and waste streams can be converted into production and consumption of these resources and Bio-productive land area of waste streams.

\section{B. Bio-productive Land}

Biologically productive land refers to land or water with ecological production capacity. Biological production refers to the accumulation of substances and energy necessary for the absorption of life in the ecosystem from the external environment into new substances in order to achieve the accumulation of matter and energy. Biological production is the natural income of natural capital causes, because natural capital is always associated with a certain surface of the Earth, so the ecological footprint analysis of the concept of biological production land to represent the natural capital. In the calculation, all kinds of resources and energy consumption items are converted into bio-productive land area.

\section{Equilibrium Factor}

In the calculation of ecological footprint, six types of land resources are usually considered: fossil energy, arable land, forest land, grassland, construction land and ocean. The six kinds of biological production area weighted sum is the ecological footprint. However, since these six types of bioproductive land have different ecological productivity, they are multiplied by an equilibrium factor in the process of weighted summation, and they are transformed into bio-productive areas with the average productivity of the global ecosystem and can be directly added The The equilibrium factor of a certain type of biological production area is equal to the average ecological productivity of the global bio-productive area of this type of global production area except for all the global bio-productive areas. The traditional algorithm used the equilibrium factor and weight: cultivated land, construction land is 2.8 , forest, fossil energy land is 1.1 , grassland is 0.5 , ocean is 0.2 .

\section{Ecological Footprint Model}

- The ecological footprint calculation formula is:

$$
E F=N e f=N \sum_{i=1}^{n}\left(r_{i} C_{i} / p_{i}\right)
$$

Where $\mathrm{i}$ is the type of consumer goods and inputs, EF is the total ecological footprint, $\mathrm{N}$ is the population, ef is the per capita ecological footprint, ri is the equilibrium factor, ci is the per capita consumption of the i-type commodity, pi is the i-class consumer goods World average production capacity. 
- The formula for calculating the ecological carrying capacity is

$$
\mathrm{EX}=\mathrm{N} \varepsilon \chi=\mathrm{N} \sum_{j=1}^{n}\left(a_{j} r_{j} / y_{j}\right)
$$

Where $\mathrm{j}$ is the type of bio-productive land, EC is the total ecological carrying capacity of the region, $\mathrm{N}$ is the population, ec is the per capita ecological carrying capacity, aj is the per capita bio-productive land area, rj is the equilibrium factor, $y j$ is the output factor.

- Comparison of ecological footprint and ecological carrying capacity When EF> EC, "ecological deficit" is not conducive to sustainable development; when EF $<$ EC, "ecological surplus" is conducive to sustainable development.

\section{E. Million Yuan GDP Ecological Footprint}

The total population (per capita) ecological footprint is divided by the total population (per capita) of gross domestic product (GDP), and the result is the ecological footprint of million GDP. The smaller the ecological footprint of GDP, indicating that the land production efficiency is higher.

\section{F. HDI Index}

The Human Development Index (HDI) is used to measure the average achievement of a country's three basic dimensions of human development: health and longevity (measured primarily at life expectancy), knowledge (up to 2/3 of adult Rate and the gross gross enrollment rate of $1 / 3$ weight) and decent living (measured by per capita GDP in dollar purchasing power). The formula is:

HDI $=1 / 3$ (life expectancy index) $+1 / 3($ education index $)+1 / 3$ (GDP index)

Among them,

Index value $=($ actual value - minimum value $) /($ maximum value - minimum value)

HDI index 3 index values are between 0 to 1,0 that the lowest level of human development, 1 that the highest level of human development.

\section{CALCULATION OF ECOLOGICAL FOOTPRINT IN GuANGDONG PROVINCE}

The biological resources of consumption in Guangdong Province mainly come from the local production and output of some biological resources is also for the input of other resources to meet the local consumption, so the biological yield can be understood as the consumption of the consumption of biological resources, because the consumption of biological resources is due to: (1) Volume; (2) due to different statistical caliber, and some biological resources, lack of data, it is difficult to deal with the data, so the use of production data instead. The production area of biological resources is calculated using the world average yield data on biological resources calculated by the FAO in 1993 (using this common standard is to make the calculation results comparable between countries, regions and regions). Because only the amount of import and export, no import and export schedules, trade adjustment part can not be calculated, so the calculation mainly by the consumption of biological resources and energy consumption in two parts.

\section{A. Biological Footprint Calculation}

The calculation method is:

$$
E F_{i}=P_{i} / Y_{\text {average }}
$$

Where $E F_{i}$ is the consumption footprint of $i$ resources; $P_{i}$ is the total output of $i$ resources; $Y_{\text {average }}$ is the average yield of $i$ resources in the world. The ecological footprint of Guangdong Province is shown in Table 1.

TABLE I. THE ECOLOGICAL FOOTPRINT OF THE BIOTIC RESOURCE

\begin{tabular}{|c|c|c|c|c|c|}
\hline Item. & 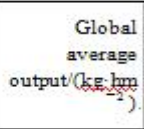 & $\begin{array}{c}\text { Biological } \\
\text { output of } \\
\text { Hubei } 10 . \mathrm{kg}\end{array}$ & $\begin{array}{r}\text { Total } \\
\text { footprints. } \\
10^{7} \mathrm{hm}^{2}\end{array}$ & $\begin{array}{c}\text { Per } \\
\text { capita } \\
\text { footprints. } \\
/\left(\mathrm{hm}^{2} \cdot \text { per }\right. \\
\left.\text { cap }^{-1}\right) .\end{array}$ & $\begin{array}{l}\text { Land } \\
\text { type }\end{array}$ \\
\hline Rice., & 2744. & 1501.68 & 0.54726 & 0.09097. & $\begin{array}{l}\text { Arable } \\
\text { land. }\end{array}$ \\
\hline Whest.r & 2744 & 176.30. & 0.06425 & 0.01068 & $\begin{array}{l}\text { Arable } \\
\text { land. }\end{array}$ \\
\hline Maize.r & 2744. & 179.13 & 0.06528 & 0.01085 & $\begin{array}{l}\text { Arable } \\
\text { land. }\end{array}$ \\
\hline Bean.? & 852. & 40.53 & 0.04757 & 0.00791. & $\begin{array}{l}\text { Arable } \\
\text { land. }\end{array}$ \\
\hline Potato., & 12607. & 16123. & 0.01279 & 0.00213 & $\begin{array}{l}\text { Arable } \\
\text { land.? }\end{array}$ \\
\hline Oil., & 1856. & 314.38 & 0.16939 & 0.02816 & $\begin{array}{l}\text { Arable } \\
\text { land. }\end{array}$ \\
\hline Cotton. & 1000. & 39.54. & 0.03954 & 0.00657 & $\begin{array}{l}\text { Arable } \\
\text { land. }\end{array}$ \\
\hline Bast.r & 1500. & 5.10 & 0.00340 & 0.00057 & $\begin{array}{l}\text { Arable } \\
\text { land. }\end{array}$ \\
\hline Suggar.: & 18000 . & 46.27. & 0.00257 & 0.00043 & $\begin{array}{l}\text { Arable } \\
\text { land. }\end{array}$ \\
\hline Vegetable.r & 18000 . & 2984.28 & 0.16579 & 0.02756 & $\begin{array}{l}\text { Arable } \\
\text { land. }\end{array}$ \\
\hline Tobacco., & 1548. & 9.82. & 0.00599. & 0.00010 & $\begin{array}{l}\text { Arable } \\
\text { land. }\end{array}$ \\
\hline Pork.r & 74. & $256.47=$ & 3.46581 & 0.57609 & Pasture \\
\hline Beef. & 33. & 16.40 & 0.49697. & 0.08261 & Pasture \\
\hline sheep.. & 33. & 6.11. & 0.18515 & 0.03078 & Pasture \\
\hline Milk., & 502. & 11.67. & 0.02325 & 0.00386 & Pasture \\
\hline Animal skin. & 15. & 24.00 & 1.60000 & 0.26595 & Pasture \\
\hline Egg. & 400. & 118.11. & 0.29528 & 0.04908 & Pasture \\
\hline $\begin{array}{l}\text { Marine } \\
\text { product. }\end{array}$ & 29. & 301.94 & $\begin{array}{r}10.411 \\
72 .\end{array}$ & 1.73064 & $\begin{array}{r}\text { Sea } \\
\text { space }\end{array}$ \\
\hline Tung sead. & 1600 & 1.34 & 0.00084 & 0.00014 & Forest. \\
\hline Walnut. $r$ & 3000. & 0.28 & 0.00009 & 0.00002 & Forest. \\
\hline Chestnut. & 3000. & $7.91=$ & 0.00264 & 0.00044 & Forest. \\
\hline Fruit.r. & 18000 . & 245.99 & 0.01367 & 0.00227 & Forest. \\
\hline $\begin{array}{l}\text { Wood(convert } \\
\left.\text { to } \log \mathrm{m}^{3}\right)\end{array}$ & 1.99. & 126.54 & 0.00636 & 0.00106 & Forest. \\
\hline
\end{tabular}
IN GUANGDONG PROVINCE

\section{B. Results Summary}

The footprints of various biological resources and energy consumption constitute the ecological footprint of Guangdong Province in 2015 (see Table 2). When calculating the supply, due to the different resource conditions or biological 
productivity in different countries and regions, it is necessary to multiply the output factor when converting into the area of biological production. According to the data, the output factors are cultivated land, construction land 1.66, forest 0.91 , grassland 0.19, water area 1.0. In addition, the proposal to report "our common future" by WCED should deduct $12 \%$ of the biodiversity conservation area in ecological capacity.

TABLE II. THE ECOLOGICAL FOOTPRINT'S SUMMARY OF HUBEI PROVINCE

\begin{tabular}{|c|c|c|c|c|c|c|c|c|}
\hline \multicolumn{4}{|c|}{ Demand of ecological footprint } & \multicolumn{5}{|c|}{ Supply of ecological capacity } \\
\hline $\begin{array}{l}\text { Land } \\
\text { type }\end{array}$ & $\begin{array}{c}\text { summary } \\
\left(\mathrm{hm}^{2} /\right. \\
\text { 人) }\end{array}$ & $\begin{array}{l}\text { Equivalence } \\
\text { factor }\end{array}$ & $\begin{array}{c}\text { Equilibrium } \\
\text { area } \\
\left(\mathrm{hm}^{2} / \text { 人) }\right.\end{array}$ & $\begin{array}{l}\text { Land } \\
\text { type }\end{array}$ & \begin{tabular}{|c|} 
Per \\
capita \\
areas \\
$/\left(\mathrm{hm}^{2}\right.$ \\
(N)
\end{tabular} & $\begin{array}{c}\text { Output } \\
\text { multiplier }\end{array}$ & $\begin{array}{c}\text { Equilibrium } \\
\text { area } \\
\left(\mathrm{hm}^{2} / \text { 人) }\right.\end{array}$ & $\begin{array}{c}\text { Ecological } \\
\text { surplus(+)or } \\
\text { ecological } \\
\text { deficit(-) }\end{array}$ \\
\hline $\begin{array}{l}\text { arable } \\
\text { land }\end{array}$ & $\begin{array}{r}0.1859 \\
34\end{array}$ & 2.8 & $0.52060+$ & $\begin{array}{l}\text { arable } \\
\text { land }\end{array}$ & $\begin{array}{r}0.089 \\
5 .\end{array}$ & $1.66+$ & $0.41600+$ & $-0.10460+$ \\
\hline forest & 0.00393 & 1.1 & $0.00432+$ & forest & $\begin{array}{r}0.128 \\
9 .\end{array}$ & 0.91 & 0.12903 & 0.12471 \\
\hline pasture & $1.00837+$ & 0.5 & 0.50419 & pasture & $\begin{array}{r}0.000 \\
9 .\end{array}$ & 0.19 & 0.00009 & $-0.50410+$ \\
\hline $\begin{array}{c}\text { Sea } \\
\text { space }\end{array}$ & 1.73064 & 0.2 & $3+$ & $\begin{array}{c}\text { Sea } \\
\text { space }\end{array}$ & $\begin{array}{r}0.037 \\
1+\end{array}$ & $1.00+$ & $0.00742+$ & -0.33871 \\
\hline $\begin{array}{l}\text { Building } \\
\text { land }\end{array}$ & 0.00109 & 2.8 & 66 & $\begin{array}{l}\text { Building } \\
\text { land }\end{array}$ & $\begin{array}{r}0.019 \\
4\end{array}$ & $1.66+$ & $0.09017+$ & $0.08711+$ \\
\hline $\begin{array}{l}\text { Fossil } \\
\text { energy } \\
\text { land }\end{array}$ & $\begin{array}{rr}0.420 & 3 \\
9 & 9\end{array}$ & 1.14 & $0.46243+$ & $\begin{array}{l}\text { Fossil } \\
\text { energy } \\
\text { land }\end{array}$ & 0 . & $0+$ & $0+$ & $-0.46243+$ \\
\hline 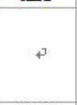 & & & & $\begin{array}{r}\text { Ecolog } \\
\text { multipl } \\
\text { protect } \\
(12 \%\end{array}$ & & & 0.07180 & \\
\hline $\begin{array}{c}\text { Total } \\
\text { demands }\end{array}$ & & & $1.84073 *$ & Total su & upply & & 0.57091 & \\
\hline Total ecol & ogical surpl & us (deficit) & & a & & & 26982 & \\
\hline
\end{tabular}

\section{Result ANALysis}

From the above calculation, it can be seen that the per capita ecological footprint of Guangdong Province in 2015 is $1.84073 \mathrm{hm}^{2}$, which can be found in comparison with other regions of the world (based on the statistical year inconsistency, only qualitative comparison here), the ecological footprint of Guangdong Province is higher than the average level of our country, But below the global average $2.20 \mathrm{hm}^{2}$ global ecological benchmark, in the global sustainable and local unsustainable level. In addition, the ecological footprint of Guangdong Province is much lower than that of economically developed countries and regions, indicating that the ecological footprint of developed countries or regions is generally higher than that of less developed countries or regions.

The ecological deficit of all kinds of land can be found: (1) The ecological deficit of grassland is the largest, reaching $0.50410 \mathrm{hm}^{2}$, which indicates the shortage and degradation trend of grassland resources. This is due to the improvement of people's living standards, food consumption structure also changes, a substantial increase in meat consumption led to the rapid increase in demand for grassland. The ecological deficit in the waters is also mainly due to the increase in consumption of aquatic products. (2) the ecological deficit in the second place is the fossil fuel land, which Guangdong Province, some high energy consumption of industrial units and residents living, heating a lot of consumption of coal, coke, crude oil and other closely related, reflecting the Guangdong Province in recent years The rapid development of industrial production. (3) Although the ecological footprint of cultivated land is the largest, but its ecological deficit is only $0.10460 \mathrm{hm}^{2}$, this is because the supply of arable land resources is relatively rich, to a certain extent, to meet the consumer demand. It is noteworthy that the shortage of arable land in Guangdong Province, if not timely control, will lead to exacerbation of deforestation and other exacerbations, and other land resources have been destroyed. (4) land types without ecological deficits are forest land and construction land, which will be conducive to the protection of forests and construction land development, the future of Guangdong Province, economic development in the forestry and real estate industry in these two areas to tap the potential.

Guangdong Province, the ecological deficit of 20151.648 $32 \mathrm{hm}^{2}$, indicating that the ecological footprint of the contradiction between supply and demand is quite prominent, the economic development is based on the excessive development of resources on the basis of human economic activities on the local ecological environment, the intensity of intensity is higher than its ecological Bearing capacity. In view of the ecological footprint calculation is the use of enumeration, each additional assessment project is likely to increase the size of the ecological footprint, this article on the consumption of biological resources in Guangdong Province enumeration is not complete, so the above results is a more optimistic estimate, Guangdong Provincial ecological footprint deficit is certainly greater than $1.64832 \mathrm{hm}^{2}$. Therefore, it can be considered that the development model of Guangdong Province is in an unsustainable state.

Guangdong Province, the ecological deficit of 20151.648 $32 \mathrm{hm}^{2}$, indicating that the ecological footprint of the contradiction between supply and demand is quite prominent, the economic development is based on the excessive development of resources on the basis of human economic activities on the local ecological environment, the intensity of intensity is higher than its ecological Bearing capacity. In view of the ecological footprint calculation is the use of enumeration, each additional assessment project is likely to increase the size of the ecological footprint, this article on the consumption of biological resources in Guangdong Province enumeration is not complete, so the above results is a more optimistic estimate, Guangdong Provincial ecological footprint deficit is certainly greater than $1.64832 \mathrm{hm}^{2}$. Therefore, it can be considered that the development model of Guangdong Province is in an unsustainable state.

\section{REFERENCES}

[1] REE W E. Ecological footprint and appropriated carrying capacity what urban economics leaves out [J].Environment and Urbanization, 1992, 4(2):196-210.

[2] Wackernagel M, Rees W. Our Ecological Footprint: Reducing human impact on the earth [M]. Gabriola Island: New Society Publishers,1996.

[3] World W F. Living planet report. 2000[EB/OL]. http://www.panda.org/downloads /general/lpr 2000.pdf, 2000-10-10.

[4] World W F. Living planet report. 2002[EB/OL]. http://www.panda.org/downloads /general/lpr 2002.pdf, 2002-06-10.

[5] World W F. Living planet report. 2015[EB/OL]. http://www.panda.org/downloads /general/lpr 2015.pdf, 2015-10-10.

[6] Wackernagel M, Onistol, Bello P, et al. Ecological footprint of Nations [M]. Commissioned by the Earth Council for the Rio 5 Forum. Toronto: International Council for Local Environmental Initiatives, 1997. 
[7] Mathis W, Lewan L, Hasson C B. Evaluating of the use natural capital with the ecological footprint: Applications in Sweden and Sub regions [J]. Ambio, 1999, 28(7) : 604-612. 